\title{
Academic Procrastination: An Exploration for the Cause at University Level
}

\author{
Saira Ijaz Ahmad ${ }^{1}$ \\ Dr. Samina Malik ${ }^{2}$ \\ Dr. Nabi Bux Jumani ${ }^{3}$
}

\begin{abstract}
Academic Procrastination is an attitude of delaying academic tasks without having any logical and conscious cause. It is a universal phenomenon that exists among the general population. The present study is an attempt to identify the academic areas in which students procrastinate at university level along with finding out the cause of Academic Procrastination. For sampling, two-stage Cluster Random Sampling Technique was used. Mainly, four departments from the Faculty of Social Sciences (Education, Psychology, Sociology, and Political Science) at University of the Punjab were randomly selected. These four sampled departments were considered as cluster for the study and all the enrolled students studying at MS/M.Phil. level were contacted for data collection. Total sample size included 78 students. PASS was adopted for data collection. Findings of the study revealed that the students at University level have moderate level of Procrastination. The major causes of Academic Procrastination are Dependency, Poor Self Confidence, Idleness, Denial, Fear to Success, Poor Time Management and Lack of Risk-Taking. Study recommended that students must be aware of the negative impacts of the phenomenon of academic procrastination.
\end{abstract}

Keywords: Academic Procrastination, University Level, Research, Education, Assignment

\section{Introduction}

Scholars and researchers have classified/defined procrastination in multiple perspectives. According to Steel (2007) procrastination is one of the less explored phenomenon and most of the work done on this phenomenon is hypothetical/theoretical rather than practical findings or work. Studies (Andreou, 2007; Simpson \& Pychyl, 2009; Steel, 2007) showed that procrastination is unjustified delay in work and the consequences will be not in favor. Abbasi and Alghamdi (2015); Steel (2007) supports the findings that when deadline of

\footnotetext{
${ }^{1}$ Lecturer, Department of Education, University of Gujrat Email: saira.usman@uog.edu.pk

${ }^{2}$ Professor of Education, Department of Education, IIUI

${ }^{3}$ Professor of Education, Department of Education, IIUI
} 
certain work approaches students give lame excuses and most of the times unable to complete task in provided time. Stead, Shanahan and Neufeld (2010) defined procrastination as a mind-set or mental disorder which is most of the times unavoidable. Schouwenburg (2004) explained procrastination as that the activity performed is different from the activity planned which has no link with laziness. Shafran and Mansell (2001) said that perfectionism is a phenomenon which is most of the time unachievable that is why a task which is planned is delayed or remain in complete. (Ferrari \& Tice, 2000; Knaus, 2000) were of the view that procrastination is a phenomenon which results in delaying, postponing or holding up a task. Moreover, procrastination is avoidable and of constant phenomenon experienced by many students. Academic procrastination is avoiding a task which is mandatory to be performed (Andreou, 2007; Steel, 2007) academic procrastination is one of the habit to protect one's self-respect (Lee, 2005).

\subsection{Rationale of the Study}

As the phenomenon of Academic Procrastination is connected and associated with the Academic Achievement of the students and in its extreme consequences this act of delaying the academic task may ruin the career of s student, the current study was an attempt to explore the Academic Tasks for which students procrastinate the most, at university level with an effort to identify the causes of Academic procrastination.

\subsection{Objectives of the Study}

Followings were the objectives of the study;

1. To find out the level of students' Academic Procrastination

2. To identify causes of Academic Procrastination

\section{Review of Literature}

A bulk of researches has been done to find out the relationship between academic Procrastination and Academic Achievement. It is evident from relevant literature that an inverse relationship exists between them. Researchers in the field of education have consensus on the debate by concluding that Academic Procrastination is simply the wastage of time as it can be classified as selfhandicapping behaviour, leading the students towards amplified level of stress and poor performance in academics (Ozer, 2011; Solomon \& Rothblum, 1984; Tice \& Baumeister, 1997; Wang \& Englander, 2010).

Anxiety, stress and phobia related to examination are negatively correlated with the students' performance and academics. It is interpreted by Onwuegbuzie and Wilson (2003) that approximately $80 \%$ of university level students perform badly in exams because of examination phobia. This examination phobia is closely linked with the attitude of delay or procrastination. Noran (2000) 
concluded that Procrastinators continuously plan and do projecting rather them achieving their objectives and always feel evaluation anxiety.

According to another discussion perfectionists are the people who set high expectations with their work (Burns, 1980; Flett \& Hewitt 2002; Frost, Marten, Lahart \& Rosenblate, 1990). Linkage between procrastination and Perfectionism remained an interest of the researcher for a long time as Burka and Yuen (1983) observed that tendency to wish constant success in career and always try to be the best are the factors that may cause delay in the working of an intellectual. Procrastination makes individuals irresponsible regarding their duties, set plans and decisions. Procrastinators avoid implementation of their decisions, break already objectives and postpone the plans up to the maximum limit (Beheshtifar \& Nasab, 2012; Dilmac, 2009).

Many other causes have been identified by the researchers that may cause delaying attitude among graduates and under-graduate students. Fear of failure (Burns et al., 2000; (Ferrari, 2001; Solomon \& Rothblum, 1984), High Frustration Level (Chang \& Zurilla, 2007; Harrington, 2006; Hoffrogge, 2001; McDermut, Haaga, \& Bilek, 2002; Stankovic \& Gvozden, 2011), Idleness (Grunschel, Patrzek, \& Fries, 2013; Neil, 2007; Steel, 2010), Poor Time Management (Noran, 2000; Vodanovich \& Seib, 1997), Peer Influence (Ammermueller \& Pischke, 2009; Graham, 2008; Hoxby \& Weingarth, 2006; Hoxby 2000; McEwan, 2003; Sacerdot, 2001; Zimmerman, 2003), Poor SelfConfidence (Hermann, Leonardelli \& Arkin, 2002; Plessis, 2006).

\subsection{Population and Sampling}

\section{Research Methodology}

For sampling, Two-stage Cluster Random Sampling Technique was used. Mainly, four departments from the Faculty of Social Sciences (Education, Psychology, Sociology, and Political Science) at University of the Punjab were randomly selected keeping in view the available financial and time resources.

These four sampled departments were considered as cluster for the study and all the enrolled students studying at MS/M.Phil. level were contacted for data collection. Total sample size for the current study was 78 students.

\subsection{Tools of the Study}

PASS (Procrastination Assessment Scale for Students) was adapted as a tool for data collection. PASS part-I helped to determine the students' level of academic procrastination. PASS part-II helped to explore the causes of students' Academic Procrastination. PASS (Procrastination Assessment Scale for Students) was developed by Solomon and Rothblum in 1984 having 66 statements in its 
three section. First two sections of PASS were adapted as per need of the present study.

\subsection{Validity \& Reliability}

Experts were contacted to ensure the validity of the tool. And reliability of the amended tool was scored on SPSS by applying Cronbach Alpha formula. The overall value of reliability was 0.88 and was considered as an acceptable value according to the interpretation of Landau and Everit (2004). They suggested that a reliable tool has above .70 value of reliability. The degree of reliability of the sub-scales was also measured. The value of reliability for part-1 of PASS was .79 and for part-II of PASS was .81, which were considered as acceptable values in the light of interpretation provided by De Vellis (1991), who suggested that a reliable tool has an above 0.50 reliability value for sub-scales.

\section{Data Analysis}

Table 1: Level of Academic Procrastination in Five Tasks

\begin{tabular}{|c|c|c|c|c|c|c|}
\hline \multirow[t]{2}{*}{ Tasks } & & & \multicolumn{4}{|c|}{ Level of Academic Procrastination } \\
\hline & & & Low & Moderate & High & Total \\
\hline \multirow[t]{2}{*}{ Research Oriented Tasks } & & $\mathrm{F}$ & 2 & 49 & 27 & 78 \\
\hline & & $\mathrm{P}$ & 2.56 & 62.82 & 34.62 & 100 \\
\hline \multirow[t]{2}{*}{ Preparation for Exams } & & $\mathrm{F}$ & 4 & 64 & 10 & 78 \\
\hline & & $\mathrm{P}$ & 5.13 & 82.05 & 12.82 & 100 \\
\hline \multirow[t]{2}{*}{ Assignments during Course } & & $\mathrm{F}$ & 2 & 58 & 18 & 78 \\
\hline & & $\mathrm{P}$ & 2.56 & 74.36 & 23.08 & 100 \\
\hline \multirow{4}{*}{$\begin{array}{l}\text { Administrative Tasks } \\
\text { Academics } \\
\text { Course Attendance }\end{array}$} & to & $\mathrm{F}$ & 1 & 51 & 26 & 78 \\
\hline & & $\mathrm{P}$ & 1.28 & 65.38 & 33.33 & 100 \\
\hline & & $\mathrm{F}$ & 1 & 43 & 34 & 78 \\
\hline & & $\mathrm{P}$ & 1.28 & 55.13 & 43.59 & 100 \\
\hline
\end{tabular}

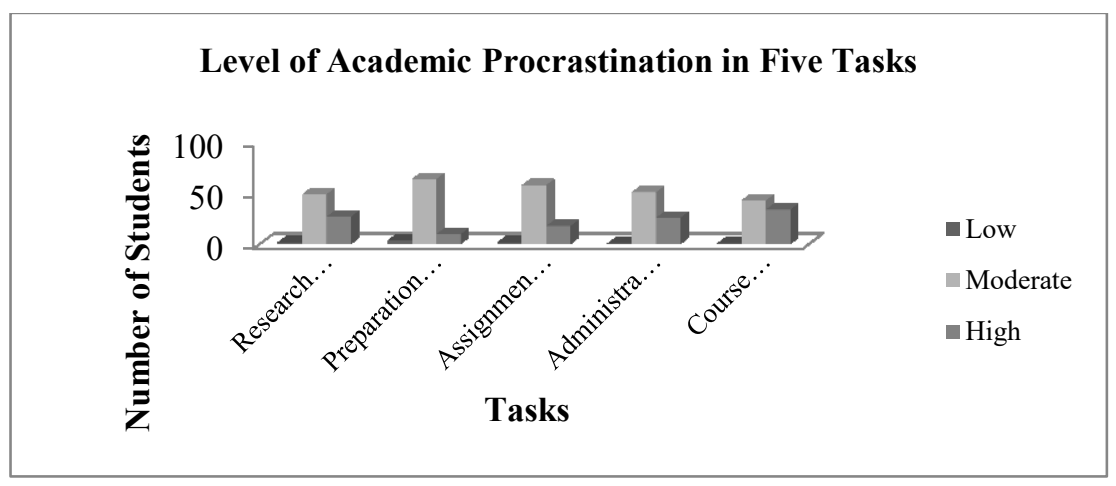

Figure 1: Level of Academic Procrastination in Five Tasks 
Table 1 and Figure 1 showed the $\mathrm{f}$ (frequency) and $\mathrm{p}$ (percentage) values regarding level of Academic Procrastination in five identified tasks. Data showed that majority of the students are Moderate Procrastinators, $62.82 \%$ in Research Oriented Tasks; $82.05 \%$ in Preparation for Exams; $74.36 \%$ in Assignments during Course; 65.38 in Administrative Tasks related to Academics; 55.13\% in Course Attendance.

Table 2: Causes of Academic Procrastination

\begin{tabular}{lllll}
\hline $\begin{array}{l}\text { Factors of Academic } \\
\text { Procrastination }\end{array}$ & $\mathrm{r}$ & $\begin{array}{l}\text { Sig. } \\
(2 \text {-tailed })\end{array}$ & $\mathrm{B}$ & $\begin{array}{l}\text { Sig. } \\
(2 \text {-tailed })\end{array}$ \\
\hline Exam Phobia & .729 & $.000^{* * *}$ & .312 & .905 \\
Perfectionism & .762 & $.000^{* * *}$ & .185 & .155 \\
Poor Decision Making Ability & .128 & $.000^{* * *}$ & .006 & .871 \\
Dependency & .551 & $.000^{* * *}$ & .606 & $.030^{*}$ \\
High Frustration Level & .522 & $.000^{* * *}$ & .056 & .444 \\
Poor Self-Confidence & .781 & $.000^{* * *}$ & .175 & $.012^{*}$ \\
Idleness & .786 & $.000^{* * *}$ & .219 & $.003^{* * *}$ \\
Denial & .786 & $.000^{* * *}$ & .206 & $.002^{* *}$ \\
Fear of Success & .808 & $.000^{* * *}$ & .354 & $.000^{* * *}$ \\
Poor Time Management & .600 & $.000^{* * *}$ & .010 & $.029^{*}$ \\
Rebel for Control & .700 & $.000^{* * *}$ & .110 & .078 \\
Lack of Risk-Taking & .312 & $.000^{* * *}$ & .130 & $.039^{*}$ \\
Peer Influence & .305 & $.000^{* * *}$ & .014 & .814 \\
Multiple Correlation R & .751 & $.000^{* * *}$ & & \\
$\mathrm{R}^{2}$ & .702 & & & \\
\hline
\end{tabular}

In table 2, Values of Pearson Correlation illustrated that identified causes have significant positive correlation with Academic Procrastination, Examination Phobia $(\mathrm{r}=.729, \mathrm{p}$-value $=.000<.001)$, Perfectionism $(\mathrm{r}=.762, \mathrm{p}$-value $=.000$ $<.001)$, Poor Decision Making Ability $(\mathrm{r}=.128, \mathrm{p}$-value $=.000<.001)$, Dependency $(\mathrm{r}=.551, \mathrm{p}$-value $=.000<.001)$, High Frustration Level $(\mathrm{r}=.522, \mathrm{p}$ value $=.000<.001)$, Poor Self Confidence $(\mathrm{r}=.781, \mathrm{p}$-value $=.000<.001)$, Idleness $(\mathrm{r}=.786, \mathrm{p}$-value $=.000<.001)$, Denial $(\mathrm{r}=.786$, $\mathrm{p}$-value $=.000<.001)$, Fear of Success $(\mathrm{r}=.808, \mathrm{p}$-value $=.000<.001)$, Poor Time Management $(\mathrm{r}=$ $.600, \mathrm{p}$-value $=.000<.001)$, Rebel for Control $(\mathrm{r}=.700, \mathrm{p}$-value $=.000<.001)$, Lack of Risk Taking $(\mathrm{r}=.312$, $\mathrm{p}$-value $=.000<.001)$ and Peer Influence $(\mathrm{r}=.305$, $\mathrm{p}$-value $=.000<.001)$. Moreover, this positive calculated correlation predicts that increase in any of these causes may increase the overall level of Academic Procrastination among students at university level; likewise decrease in any of these identified causes may minimize the level of Academic Procrastination among students at university level. These values of correlation are significant at $95 \%$ level of confidence.

The standardized regression weights indicate that seven causes Dependency $(\beta .606, p=.030<0.05)$, Poor Self Confidence $(\beta .175, p=.012<0.05)$, Idleness 
$(\beta .219, \mathrm{p}=.003<0.01)$, Denial $(\beta .206, \mathrm{p}=.002<0.01)$, Fear to Success $(\beta$ $.354, \mathrm{p}=0.000<0.01)$, Poor Time Management $(\beta .010, \mathrm{p}=.029<0.05)$ and Lack of Risk-Taking $(\beta .130, p=0.039<0.015)$ are statistically significant while the other six identified reasons Examination Phobia $(\beta .312, \mathrm{p}=.905)$, Perfectionism ( $\beta .185, \mathrm{p}=.155)$, Poor Decision Making Ability $(\beta .006, \mathrm{p}=.871)$, High Frustration Level $(\beta .056, \mathrm{p}=.444)$, Poor Time Management $(\beta .110, \mathrm{p}=$ $.078)$, Peer Influence $(\beta .014, \mathrm{p}=.814)$ are insignificant. The Multiple Correlation value $(\mathrm{R}=.751)$ was significant (with $95 \%$ significance level) and $\mathrm{R}^{2}$ value (.702) advocated that thirteen identified causes are contributing $70 \%$ towards students' Academic Procrastination tendency.

\section{Conclusions}

The findings of the study revealed that majority of the students at university level are Moderate Procrastinators. It is concluded that $62.82 \%$ students at university level procrastinate their Research Oriented Tasks, 82.05\% procrastinate Preparation for Exams, $74.36 \%$ did not submit their Assignments during Course on due dates, $65.38 \%$ unenthusiastic to perform their Academic Administrative Tasks on scheduled time, and 55.13\% were reluctant for Course Attendance. They have concluded that majority $(67 \%)$ of undergraduates have a medium level of procrastination.

The study revealed seven causes as significant predictor of Academic Procrastination. These included Dependency, Poor Self Confidence, Idleness, Denial, Fear to Success, Poor Time Management and Lack of Risk-Taking.

\section{Discussion}

The present study was an attempt to study the phenomenon of Academic Procrastination with the exploration of its causes. The study has highlighted that majority of the students procrastinate their research oriented tasks. These findings are in line with Mahasneh, Bataineh and Al-Zoubi (2017). Students are dependent in research oriented tasks. Dependency was assessed as one of the powerful predictor of Academic Procrastination (also studied by Steel (2007). Poor Self-Confidence (also identified by Plessis in 2006), Idleness (also studied by Van Eerde in 2003), Denial (also identified by Grunschel, Patrzek, \& Fries in 2013), Fear to Success (also studied by Cox, Clara \& Enns in 2009), Poor Time Management (also identified by Dusselier et al., in 2005) and Risk-Taking were explored as the causes of Academic Procrastination in present study.

\section{Recommendations}

The conclusions of the study highly recommend that student have a tendency to delay and prolong their Academic Tasks at university level. They procrastinate their Research Oriented Tasks at large or with great tendency. Teacher may focus 
the research areas specifically and all the academic areas in general to guide the students so that they will be able to reduce the tendency of delay. Student most of the times feel that they cannot do their work independently, they are unable to manage their time properly. They feel lack of confidence. All these areas are in fact the causes of Academic Procrastination. Both teachers and students have to pay attention toward these highlighted areas to minimize the trend of procrastination among students.

\section{References}

Abbasi, I. S. \& Alghamdi, R. G. (2015). The prevalence, predictors, causes, treatment, and implications of procrastination behaviours in general, academic, and work settings. International Journal of Psychological Studies, 7, 59-66.

Ammermueller, A. \& Pischke, J. (2009). Peer effects in European primary schools: Evidence from PIRLS. Journal of Labor Economics, 27(3), 315348 .

Andreou, C. (2007). Understanding procrastination. Journal for the Theory of Social Behaviour, 37, 183-193.

Beheshtifar, M. \& Nasab, H. (2012). Effect Procrastination Behaviour on Organization-Based Self-Esteem. Innova Ciencia, 4(1), 55-63.

Burka, J. B. \& Yuen, L. M. (1983). Procrastination: Why you do it. What to do about it. Reading, MA: Addison-Wesley.

Burns, D. D. (1980). The perfectionist's script for self-defeat. Psychology Today, November, 34-52.

Burns, L., Dittmann, K., Nguyen, N. \& Mitchelson, J. (2000). Academic procrastination, perfectionism, and control: Associations with vigilant and avoidant coping. Journal of Social Behaviour \& Personality, 15(5), 35-46.

Chang, C. E. \& Zurilla, J. T. (2007). Irrational beliefs as predictors of anxiety and depression in a college population. Personality and Individual Differences, 20(2), 215-219.

Cox, B. J., Clara, I. P. \& Enns, M. W. (2009). Self-Criticism, maladaptive perfectionism, and depression symptoms in a community sample: A 
longitudinal test of the mediating effects of person-dependent stressful life events. Journal of Cognitive Psychotherapy, 23(4), 336-349.

De Vellis, R. F. (1991). Scale development: Theory and application. Newbury Park: Sage Publications.

Dilmac, B. (2009). An Analysis of Teachers' General Tendency to Procrastinate, Perception of Professional Efficiency/Self Efficiency and Altruism. Electronic Journal of Research in Educational Psychology, 7(3), 13231338 .

Dusselier, L., Dunn, B., Wang, Y., Shelley, M. C. \& Whalen, D. F. (2005). Personal, health, academic, and environmental predictors of stress for residence hall students. Journal of American College Health, 54, 15-24.

Ferrari, J. R. \& Tice, D. M. (2000). Procrastination as a self-handicap for men and women: a task-avoidance strategy in a laboratory setting. Journal of Research in Personality, 34, 73-83.

Ferrari, J. R. (2001). Procrastination as self-regulation failure of performance: effects of cognitive load, self-awareness, and time limits on "working best under pressure". European Journal of Personality, 15, 391-406.

Flett, G. L. \& Hewitt, P. L. (2002). Perfectionism and maladjustment: An overview of theoretical, definitional, and treatment issues. In P. L. Hewitt \& G. L. Flett (Eds.), perfectionism (pp. 5-31). Washington, DC: American Psychological Association.

Frost, R. O., Marten, P., Lahart, C. \& Rosenblate, R. (1990). The Dimensional of perfectionism. The Cognitive Therapy and Research, 14(5), 449-468.

Graham, B. (2008). Identifying social interactions through conditional variance restrictions. Econometrica, 76 (3), 643-660.

Grunschel, C., Patrzek, J. \& Fries, S. (2013). Exploring the Reasons and Consequences of Academic Procrastination: An Interview Study. European Journal of Psychology of Education, 28, 841-861.

Harrington, N. (2006). Frustration intolerance beliefs: Their relationship with 
depression, anxiety, and anger, in a clinical Population. Cognitive Therapy and Research, 30(6), 699-709.

Hermann, A. D., Leonardelli, G. J. \& Arkin, R. M. (2002). Self-doubt and selfesteem: A threat from within. Personality and Social Psychology Bulletin, $28,395-408$.

Hoffrogge, J. (2001). Academic procrastination: Low Frustration Tolerancebehaviour correlates. Journal of Counseling Psychology, 31, 503-509.

Hoxby, C. \& Weingarth, G., (2006). Taking Race Out of the Equation: School Reassignment and the Structure of Peer Effects. Retrieved from https://www.pausd.org/sites/default/files/pdf-faqs/attachments/ TakingRaceOutOfTheEquation.pdf

Hoxby, C. (2000). Peer Effects in the Classroom: Learning from Gender and Race Variation. NBER Working Paper 786.

Knaus, W. J. (2000). Procrastination, blame, and change. Journal of Social Behaviour and Personality, 15, 153-166.

Landau, S. \& Everitt, B. S. (2004). A Handbook of Statistical Analyses Using SPSS. CRC Press.

Lee, E. (2005). The relationship of motivation and flow experience to academic procrastination in university students. The Journal of Genetic Psychology: Research and Theory on Human Development, 166(1), 5-15.

Mahasneh, A. M., Bataineh, O. T., \& Al-Zoubi, Z. A. (2017). The Relationship between Academic Procrastination and Parenting Style among Jordanian Undergraduate University Students. The open Psychology Journal, 10, 2534.

McDermut, J. F., Haaga, D. A. F. \& Bilek, L. A. (2002). Cognitive bias and irrational beliefs in major depression and dysphonia. Cognitive Therapy and Research, 21(4), 459-476.

McEwan, P. J. (2003). Peer effects on student achievement: Evidence from Chile. Economics of Education Review, 22, 131-141. 
Neil, A. F. (2007). Now Habit: A strategic Program for overcoming procrastination and enjoying guilt-free play paperback. USA: Penguin Group Publishers Inc.

Noran, F. Y. (2000). Procrastination among students in institutes of higher learning: Challenges for K-Economy. Retrieved from $\mathrm{http} / /$ www.mahdzan.com/papers/ procrastinate

Onwuegbuzie, A. J. \& Wilson, V. A. (2003). Economics anxiety: nature, ethology, antecedents, effects and treatments: a comprehensive review of the literature. Teaching in Higher Education, 8, 195-209.

Ozer, B. U. (2011). A Cross Sectional Study on Procrastination: Who Procrastinate More? International Conference on Education, Research and Innovation, IPEDR, 18, 34-37.

Plessis, D. (2006). Self Confidence, Fear and the Inevitable Procrastination. Retrieved from http://www.selfimprovement-gym.com

Sacerdote, B. (2001). Peer Effects with Random Assignment: Results for Dartmouth Roommates. Quarterly Journal of Economics, 116(2), 681704.

Schouwenburg, H. C. (2004). Trait procrastination in academic settings: An overview of students who engage in task delays. In H. C. Schouwenburg, C. Lay, T. Pylchyl, \& J. Ferrari, (Eds.), Counselling the procrastinator in academic settings (pp. 3-18). Washington: American Psychological Association.

Shafran, R. \& Mansell, W. (2001). Perfectionism and Psychopathology: A review of research and treatment. Clinical Psychology Review, 21, 879906.

Simpson, W. K. \& Pychyl, T. A. (2009). In search of the arousal procrastinator: Investigating the relation between procrastination, arousal-based personality traits and beliefs about procrastination motivations. Personality and Individual Differences, 47, 906-911.

Solomon, L. J. \& Rothblum, E. D. (1984). Academic procrastination: Frequency 
and cognitive-behavioural correlates. Journal of Counselling Psychology, $31,503-509$.

Stankovic, S. \& Vukosavljević-Gvozden, T. (2011). The relationship of a measure of frustration intolerance with emotional dysfunction in a student sample. Journal of Rational-Emotive \& Cognitive-Behaviour Therapy, 29(1), 17-34.

Stead, R., Shanahan, R. \& Neufeld, W. J. (2010). I'll go to therapy eventually: Procrastination, stress and mental health. Personality and Individual Differences, 49, 175-180.

Steel, P. (2007). The Nature of Procrastination: A Meta-Analytic and Theoretical Review of Quintessential Self-Regulatory Failure. Psychological Bulletin, 133(1), 65-94.

Steel, P. (2010). The Procrastination Equation: How to Stop Putting Things Off and Start Getting Stuff Done. New York: HarperCollins.

Tice, D. M. \& Baumeister, R. F. (1997). Longitudinal study of procrastination, performance, stress, and health: The costs and benefits of dawdling. Psychological Science, 8, 454-458.

Van-Eerde, W. (2003). Procrastination at work and time management training. Journal of Psychology, 137(5), 421-434.

Vodanovich, S. J. \& Seib, H. M. (1997). Relationship between time structure and procrastination. Psychological Reports, 80, 211-215.

Wang, Z. \& Englander, F. (2010). A cross-disciplinary perspective on explaining student performance in introductory Economics - What is the relative impact of procrastination? College Student Journal, 44(2), 458-471.

Zimmerman, D. J. (2003). Peer Effects in Academic Outcomes: Evidence from a Natural Experiment. Review of Economics and Economics, 85(1), 9-23. 